\title{
The effect of formative assessment on high school students' mathematics achievement and attitudes
}

\author{
Yusuf Ziya Kültürr ${ }^{1}$ and Mahmut Oğuz Kutlu² \\ ${ }^{1}$ Ministry of National Education, Turkey (ORCID: 0000-0001-9082-7316) \\ ${ }^{2}$ Çukurova University, Faculty of Education, Turkey (ORCID: 0000-0002-6539-2354)
}

\begin{abstract}
The purpose of this research is to examine the effects of formative assessment practices on students' academic achievement, attitudes towards mathematics, and to investigate their views on formative assessment practices. A 12-week quasi-experimental research design was adopted in the research. The research group consisted of 51 students in the 10th grade (26 in the experimental group and 25 in the control group) of a high school. Qualitative data were obtained via functions academic test and mathematics attitude scale while a semi-structured interview form was used as a qualitative data collection tool. The quantitative results revealed that the effect of formative assessment practices on students' attitudes towards mathematics and mathematics achievement was statistically significant. According to the qualitative results of the research, formative assessment practices were found to be beneficial in terms of contributing to learning processes and encouraging students to express themselves in the classroom. It is recommended that teachers use formative assessment to support student-centered classrooms in teaching mathematics and to effectively evaluate students' mathematical competence in the learning process.
\end{abstract}

Keywords: Formative assessment; Teaching mathematics; Academic achievement; Attitude

Article History: Submitted 13 May 2021; Revised 23 September 2021; Published online 29 December 2021

\section{Introduction}

Evaluation plays a central role in education (Baird et al., 2017). However, the effect of summative assessment in education on improving during instruction is limited (Schoenfeld, 2016). Although different assessments are used as part of the teaching process, effective teachers should use formative assessment in the classroom to identify student misunderstandings, provide feedback to students, and make necessary corrections in teaching (Cauley \& McMillan, 2010). Because formative assessment, which focuses on the enhancement of learning rather than assessment what has been learned, is one of the important tools for success in education (Box, 2019; Gotwals et al., 2015; Moreno \& Pineda, 2020). The use of formative assessment in mathematics classrooms is necessary to provide students with opportunities to review their knowledge, reflect, and improve the quality of their learning (Swan \& Foster, 2018). Formative assessment is a dynamic process used by teachers and students that provide information to be used as feedback to improve

Address of Corresponding Author

Yusuf Ziya Kültür, Şehit Serkan Yılmaz Anatolian High School, 46100 Kahramanmaraş, Turkey.

$\triangle$ yusufziyakultur@gmail.com

How to cite: Kültür, Y. Z. \& Kutlu, M. O. (2021). The effect of formative assessment on high school students' mathematics achievement and attitudes. Journal of Pedagogical Research, 5(4), 155-171. https://doi.org/10.33902/JPR.2021474302 
learning during instruction (Wylie, 2020). In formative assessment, students actively participate in learning processes to achieve goals (Xiao, \& Yang, 2019). Formative assessment in the classroom should be applied within a certain framework. Wiliam and Thompson (2007) identified those five basic strategies that support formative assessment practices in the classroom: 1) Clarification of learning goals and criteria for success, 2) designing effective classroom discussions and other learning tasks that elicit evidence of student understanding, 3) providing feedback that moves students forward, 4) activating students as instructional resources for each other, and 5) activating students as owners of their own learning.

The main factors guiding the formative assessment process are learning goals and success criteria (Beesley et al., 2018). The most effective formative assessment takes place when students have a clear idea of what teachers expect from them (Cauley \& McMillan, 2010). For students to evaluate their work, they must have information about the goals (Frey et al., 2018). Thus, they can follow the learning process (Moss \& Brookhart, 2019). In this way, higher participation and satisfaction in students' academic progress is achieved (Box, 2019). Teachers and students must constantly interact in social contexts in the classroom (Crossouard, 2011). From this point of view, teachers and students are active participants in formative assessment processes (Fisher \& Frey, 2014). The role of the teacher in the process of students learning from their peers is to inform students about their own learning levels with reinforcement and feedback (Schunk, 2012). Students' role is to take responsibility for the learning process (Box, 2019).

According to Sadler (1989), feedback is "an important element in formative assessment and is generally defined as information about how successful something is" (p.120). From a cognitive perspective, feedback can often be regarded as a source of information needed to improve a task (Wisniewski et al., 2020).Feedback also provides students with an awareness of their own thoughts and helps them develop self-evaluation skills (Moss \& Brookhart, 2019). Hattie and Clarke (2018) emphasized that feedback is an effective tool to enhance learning. In this respect, feedback plays a critical role in formative assessment (Ardington \& Drury, 2017; Box, 2019; Cramp, 2011; Sadler, 1989).

Self-assessment is one of the most commonly used activities in the classroom (Panadero \& Alonso-Tapia, 2013). It is the act of observing, analyzing, and evaluating a student's own performance based on criteria and determining how to improve it (Moss \& Brookhart, 2019). The primary purpose of engaging students in careful self-assessment is to increase learning and achievement (Martin, 2010). Through self-assessment, the teacher should organize the teaching processes in line with the students' needs and guide the students in setting personal goals (Box, 2019). Studies have shown that self-assessment has positive effects on learning strategies such as motivation and self-efficacy (Panadero et al., 2017). On the other hand, it was seen that self and peer assessment contributed to the development of students' assessment judgments (Tai et al., 2018).

In formative assessment, the students' role in the classroom is to support each other's learning. This is done by peer evaluation (Andersson \& Palm, 2017). The teacher should create a positive environment in the classroom where students can communicate positively with each other and feel comfortable and effective in their social relations (Bower et al., 2015). The social and emotional support that the teacher provides to the students enables the students to establish strong and healthy relationships with each other in the classroom (Barber \& Schluterman, 2008).

Self and peer assessment is a very efficient way to promote learning with formative activities (Wanner \& Palmer, 2018). Peer assessment provides an opportunity for students to express the misconceptions that they cannot express during the lesson (Martin, 2010). However, the explanations and questions that the students deliver to each other during their interactions give clues to the teacher about the students' current understanding. Studies have found that self and peer assessment can improve students' learning (Wanner \& Palmer, 2018), and peer assessment has been found to have a positive effect on metacognitive awareness and self-efficacy (Zheng et al., 2018). 
Mathematics achievement in Turkey remains well below the desired level and mathematics is seen as a feared subject for students (Altıparmak et al., 2017). In order to develop more effective and efficient tools in mathematics teaching, it is necessary to carry out studies on the development of new learning approaches (Selçuk et al., 2014; Yalçınkaya \& Özkan, 2012). The subject of functions is one of the most fundamental subjects of mathematics (Teuscher \& Reys, 2010). It has been revealed by many studies that students have misconceptions and difficulties in the learning process about functions. However, there are very few studies on teaching the concept of function in the literature (Özgen \& Alkan, 2014). Studies have shown that formative assessment is a powerful tool for increasing students' achievement in mathematics (Andersson \& Palm, 2017; Cauley \& McMillan, 2010; Chen et al., 2020) and has positive effects on student motivation (Beesley et al., 2018; Faber et al., 2017). Studies conducted in mathematics education in Turkey evident that the number of studies carried out at high school level is insufficient (Er \& Biber, 2020). However, studies consider education and evaluation together in high school mathematics education is still faded. The purpose of this research is to examine the effects of formative assessment practices on students' academic achievement, attitudes towards mathematics, and their views on formative assessment practices.

\subsection{Purpose of the Research}

The aim of this study is to examine the effects of formative assessment practices on 10th-grade students' attitudes towards mathematics lessons, as well as their academic achievement and views on formative assessment practices. The following questions were asked:

Is there a significant difference between the functions achievement and mathematics attitude scale pre-test scores of the experimental and control group students?

$>$ Is there a significant difference between pre-, post-, and retention functions achievement test scores of experimental and control group students?

$>$ Is there a significant difference between the experimental and control group students' mathematics attitude scale pre and post test scores?

$>$ What are the students' views on formative assessment practices?

\section{Method}

\subsection{Research Design}

This mixed-methods study utilized an embedded quasi-experimental design. In embedded designs, quantitative data are mostly supported by qualitative data (Büyüköztürk et al., 2019). However, quantitative and qualitative data are collected simultaneously or respectively during the research process, and data sets are analyzed separately as they relate to different research questions (Edmonds \& Kennedy, 2017). In the quantitative dimension of the study, a quasiexperimental design with pre-test and post-test control groups was used. The qualitative dimension of the research consists of student views on formative assessment practices.

\subsection{Participants}

The research was conducted in a provincial center in the Southern region of Turkey. The research group consisted of 51 students in the 10th grade of a high school in the 2019-2020 academic years. The experimental and control groups were randomly assigned from among the 4 classes of 10th graders, without changing the class structures. The control group consisted of 25 students and the experimental group consisted of 26 students (aged 15-16). The pre-test scores of the experimental and control groups revealed that the groups did not differ statistically in terms of academic achievement and attitude towards mathematics scores before manipulation. Students in the study groups were 34 females $(66.66 \%)$ and 17 males (33.33\%). All the students in the groups voluntarily participated in the research. Consent was obtained from the families of the students before the enrollment. 
Maximum diversity sampling, which is one of the purposeful sampling types, was used to determine the interview group. The purpose of maximum variation sampling is to describe the situation under consideration in a broad framework (Büyüköztürk et al., 2019). Experimental group students were divided into three groups in terms of their functions achievement post-test scores as lower, middle and upper. An interview group was formed with 5 volunteers from each of these groups. Permission was obtained from the families of 15 students in the interview group. Random nicknames assigned to each participant in the qualitative findings.

\subsection{Instruments}

The functions achievement test (FAT) and mathematics attitudes scale (MAS) were used as quantitative data collection instruments. Qualitative data collected through the semi-structured interview form (SSIF).

\subsubsection{Functions achievement test (FAT)}

The FAT was prepared by the researcher according to the aims of the functions topic. The test was reviewed by three experts to check the content validity. The FAT draft form consisted of 50 multiple-choice questions. It was applied to a total of 263 students in the 2018-2019 academic years. The values were determined for the item distinction index and the item difficulty coefficient of the test. Through a test of internal consistency, the number of questions was reduced to 20 . The distribution of the questions according to the acquisitions (Ministry of National Education [MoNE], 2018) is presented in Table 1.

Table 1

Table of acquisitions for the FAT

\begin{tabular}{lc}
\hline Acquisitions & Number of questions \\
\hline Solves problems related to functions. & 5 \\
Draws graphs of functions. & 2 \\
Interprets graphs of functions. & 2 \\
Expresses real life situations with linear functions and makes graphical & 3 \\
representations. & 1 \\
Makes applications related to one-to-one and onto functions. & 4 \\
performs operations on composite functions & 3 \\
Finds the inverse of a given function. & 20 \\
Total & \\
\hline
\end{tabular}

The average difficulty index of the FAT was calculated as 0.56 , while the average discrimination index was 0.53 . The $\mathrm{Kr}-20$ reliability coefficient was calculated as 0.89 .

\subsubsection{Attitudes towards mathematics scale (MAS)}

The MAS was developed by Yaşar et al. (2014) to measure the attitudes of high school students towards mathematics. This scale was preferred because it was developed in accordance with the age and education level of the students in the research group. The scale consists of 35 items answered in a five-point Likert-type system. The scale was developed with the options of "strongly agree (5)," "agree (4)," "neutral (3)," "disagree (2)," and "strongly disagree (1)." A low of 35 points and a high of 175 points could be obtained on the scale. The Cronbach alpha reliability coefficient of the scale was calculated to be $\alpha=.93$ as a result of the reliability analysis of the MAS pre-tests applied to the experimental and control groups. The MAS scale consists of four factors. Cronbach alpha reliability coefficients of these factors; (i) enjoying ( $\alpha=.86)$, (ii) fear, anxiety and boredom $(\alpha=.88)$, (iii) place of mathematics in life, $(\alpha=.81)$ and (iv) perceived mathematics success $(\alpha=.92)$. Approval was obtained from the authors for the use of MAS. 


\subsubsection{Semi-Structured Interview Form (SSIF)}

SSIF was developed by the researcher to examine the views of students towards formative assessment practices. SSIF was scrutinized by four specialists for content validity. Before the manipulation process interviews were held with five students who outside the interview group of the study and the questions were finalized in line with the feedback. SSIF consisted of four openended questions (see Appendix 1).

\subsection{Process}

Formative assessment activities should be carried out together as formal and informal activities (Cowie \& Moreland, 2015). Formal and informal formative assessment practices were determined to be used in the quasi-experimental process. The acquisitions in the 10th grade functions unit of the high school mathematics curriculum were taken as basis in the process of determining formative assessment practices (see Table 1). Lesson plans have been prepared for the use of formative assessment practices. Five basic strategies of the formative assessment framework were taken as the basis in this process; (i) Clarification of learning goals and criteria for success, (ii) Designing effective classroom discussions and other learning tasks that elicit evidence of student understanding, (iii) Providing feedback that moves students forward, (iv) Activating students as instructional resources for each other, and (v) Activating students as owners of their own learning. Formative assessment practices and lesson plans were reviewed by three experts and corrections were made. One of the formative assessment applications used in the manipulation process is reflective prompts.

\subsubsection{Reflective prompts}

Reflective prompts were used as an application that encourages metacognitive thinking about students' classroom experiences (Keeley, 2015). Reflective prompts were used to determine the views of all the students in the experimental group about their course experiences and formative assessment practices.

The pilot study and quasi-experimental procedure were conducted by the first author. The pilot study was conducted with twenty-seven $10^{\text {th }}$ grade students at a high school in 2018-2019 academic year. The pilot study lasted for seven weeks. The duration of the course contents was determined and necessary corrections were made before the quasi-experimental procedure.

The research process was completed in 12 weeks. The FAT and MAS pre-tests were applied to the experimental and control groups in the first week. The study was completed in 7 weeks, excluding pre-test and post-test practices. The "Functions" unit was the same for the two groups, but the lessons in the experimental group were conducted based on formative assessment practices. Lessons in the control group were conducted in accordance with the current curriculum. Short-term formative assessment techniques were preferred (Eddy et al., 2017). Based on the five basic strategies of the formative assessment framework, the following practices were included in the mathematics lessons in the experimental group.

Clarifying and sharing learning intentions and criteria for success. At the beginning of the lessons, the learning targets were shared with students by discussing them and writing them on the board or during activities. Students were asked to research the parts of the topics related to daily life and share them with the class. The teacher clearly stated the learning objectives and criteria for success. At the end of the lesson or at the beginning of the next lesson, the students were asked to express their opinions about what they learned, in writing or orally.

Designing effective classroom discussions and other learning tasks that elicit evidence of student understanding. Written or oral questions were asked of the students to reveal learning evidence. Students were asked to write, on the board, the questions they did not understand in the previous lesson and to share them with the class. Questions were asked that encouraged the students to think at a higher level. Time was given to reflect on the questions. Then, students were 
asked to discuss their answers in small groups. Students' discussions were followed by the teacher, and common mistakes and gaps in teaching were identified. Students were encouraged to express their opinions about the solutions to the questions. So that the whole class would actively participate in the learning process, questions were asked not only of those students who knew about the subject but also of students randomly selected from the list. Examples from in-class practices are as presented in Figure 1.

Figure 1

Reflection from classroom practices
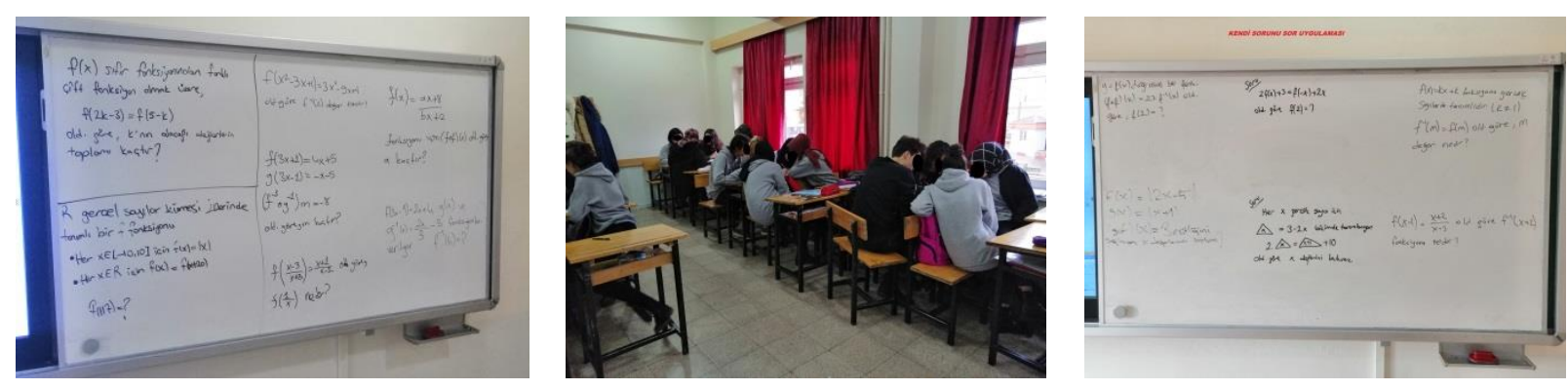

Providing feedback that moves students forward. When feedback was given to the students, no grading was done. Students were not compared to others. The parts they had to think about and the areas in which they would improve were highlighted. As a result of student responses and group discussions, the problems in teaching were eliminated by making arrangements in education. Paired or small group work, individual activities, and whole-class discussions were used in providing feedback to the students.

Activating students as owners of their own learning. Students were informed about selfassessment. As part of the evaluation process, they were asked to evaluate their own learning processes. Students were guided in adjusting their own learning. Reflective prompts were used as a practice encouraging metacognitive thinking to determine students' classroom experiences, what they learned in the lesson, the areas in which they had learning difficulties, and how they could overcome these difficulties (Keeley, 2015). At the end of the lesson, students were encouraged to talk about what they had learned in the lesson.

Activate students as instructional resources for each other. Efforts were made to create a positive environment in which students could communicate with each other in the classroom. It was ensured that the study groups were formed with different students each time. Self and peer assessments were frequently used in the process. Students were supported socially and emotionally. Interaction, mutual respect, and performance goals were encouraged in the classroom. The explanations that the students gave to each other and the questions they asked were used to guide the teaching process that the teacher followed.

Lessons in the control group were conducted in accordance with the current curriculum. The FAT and MAS post-tests were applied to the experimental and control groups in the 9th and 10th weeks of practice. Based on the FAT post-test results of the experimental group, the students to be interviewed were determined and the interviews were carried out. FAT retention test was applied to the experimental and control groups 4 weeks after the end of the quasi-experimental practice.

Student interviews were conducted at the conclusion of implementation. After the FAT posttest was applied to the experimental group students were informed that bilateral interviews would be conducted on the experimental procedure process. It was stated that participation in the interview is optional. The interview group consists of 15 students. Permission was obtained from the families of 15 students in the interview group. Interviews were conducted at predetermined times, consistent with the semi-structured interview form. Interviews were performed in a separate room at the school. The duration of the interview with each student lasted 10 to 20 
minutes. Interviews recorded. In order to make the students feel comfortable during the interview, it was ensured that there were no other people in the room except the student and the interviewer. During the interview, the questions in the semi-structured interview form were asked to the students. Additional explanations were made when necessary, allowing students to express their thoughts.

\subsection{Data Analysis}

\subsubsection{Quantitative data analysis}

Because both FAT and MAS data approximated normal distribution and that their variances were equal, parametric statistical analyses requiring the assumption of normality in these data sets were made in the following order: 1) Independent groups t-test was used to determine whether a significant difference exists between the FAT and MAS pre-test scores of the students in the experimental and control groups. 2) Two-way analysis of variance (ANOVA) was used for mixed measures to examine whether there was a statistically significant difference between the groups in terms of FAT and MAS scores. 3) In the process of interpreting the analysis results, the significance level was accepted as .05 , and the effect size values as low $=.01$, medium $=.06$, and high $=.14$ (Cohen, 1988, pp. 285-287).

Before performing the analysis, it was determined that the assumptions of normality and homogeneity of variances were met, among the assumptions of two-way analysis of variance (ANOVA) for mixed measurements. No statistically significant difference was determined between the covariances $(p>0.5)$. It was also determined that the assumption of sphericity was fulfilled $\left(\chi^{2}(2)=0.48, p>0.5\right)$.

\subsubsection{Qualitative data analysis}

The analysis of the qualitative data obtained from the research was carried out by content analysis. Interviews with the experimental group students were recorded. In the process of converting audio recordings into qualitative findings, three coders (two experts and the researcher) were included to ensure reliability. The percentage of agreement between coders was calculated using the formula "Reliability $=$ [Consensus / (Total Consensus + Disagreement)] x 100" (Miles \& Huberman, 1994, p. 64). The percentage of agreement between coders was determined as (91\%).

\subsection{Validity and Reliability}

All the processes of the research were conducted by the first author, adhering to the current theoretical framework and application stages of the research. Lesson plans have been prepared for the use of formative assessment practices. Five basic strategies of the formative assessment framework were taken as the basis in this process; (i) Clarification of learning goals and criteria for success. (ii) Designing effective classroom discussions and other learning tasks that elicit evidence of student understanding. (iii) Providing feedback that moves students forward. (iv) Activating students as instructional resources for each other. (v) Activating students as owners of their own learning (Wiliam \& Thompson, 2007). Formative assessment practices and lesson plans were reviewed by three experts and corrections were made. The lesson plans included the acquisitions, process, activities to be implemented and adjusting the time. The implementation process took 7 weeks (42 Lessons of 40 minutes each). The lessons in the experimental and control groups were conducted by the first author. The second author participated in the teaching process as an observer.

The pre-tests applied to the experimental and control groups revealed that the groups did not differ significantly in terms of achievement test and attitude scores towards mathematics. Validity and reliability studies of measurement tools have been done. Before the implementation, a pilot study was conducted to minimize the problems that could arise. The margin of error that could arise from measurement did not differ in terms of the experimental and control groups. There was no loss of subjects in the experimental and control groups during the quasi-experimental 
procedure. Detailed information about the research was not given to the experimental and control groups in order to avoid any expectation about the results of the research. The groups were not informed about the purpose of the application of the measurement tools and the date of the measurement before the application. So that the measurements would not affect each other, no feedback was given to the students after the measurement, and the students were not allowed to take questions or answers.

Student interviews were conducted by the first author. After the FAT post-test was applied to the experimental group students were informed that bilateral interviews would be conducted on the experimental procedure process. It was stated that participation in the interview is optional. The interview group consists of 15 students. Permission was obtained from the families of 15 students in the interview group. Interviews were conducted at predetermined times, consistent with the semi-structured interview form. Interviews were performed in a separate room at the school. The duration of the interview with each student lasted 10 to 20 minutes. In order to make the students feel comfortable during the interview, it was ensured that there were no other people in the room except the student and the interviewer. During the interview, the questions in the semi-structured interview form were asked to the students. Additional explanations were made when necessary, allowing students to express their thoughts.

\section{Findings}

\subsection{FAT and MAS Pre-test Scores of Experimental and Control Group Students}

To test whether there was a statistically significant difference between the FAT and MAS pre-test scores of the experimental and control group students, an independent groups t-test was performed. The results are presented in Table 2.

Table 2

Independent samples t-test results of the FAT and MAS pre-test scores of the two groups

\begin{tabular}{lllccccc}
\hline Dependent Variable & \multicolumn{1}{c}{ Group } & $N$ & Mean & $S D$ & $d f$ & $t$ & $p$ \\
\hline \multirow{2}{*}{ FAT } & Experimental & 26 & 7.50 & 6.52 & \multirow{2}{*}{49} & \multirow{2}{*}{0.59} & \multirow{2}{*}{.954} \\
& Control & 25 & 7.60 & 5.61 & & & \\
MAS & Experimental & 26 & 116.69 & 16.63 & \multirow{2}{*}{49} & 0.208 & .836 \\
\hline
\end{tabular}

Table 2 shows that there was no statistically significant difference between the FAT and MBI pre-test scores of the experimental and control group students before the quasi-experimental procedure $(t=.59 ; p>.05, t=.208 ; p>.05)$.

\subsection{Pre-, Post-, and Retention Test FAT Scores of Experimental and Control Group Students}

The arithmetic mean and standard deviation values of the experimental and control group students' pre-, post-, and retention test FAT scores are presented in Table 3.

Table 3

Descriptive Data of Experimental and Control Group Students' Pre-, Post-, and Retention Test FAT Scores

\begin{tabular}{lccccccccc}
\hline & \multicolumn{3}{c}{ Experimental Group } & \multicolumn{4}{c}{ Control Group } & \multicolumn{3}{c}{ Total } \\
\hline & $\mathrm{N}$ & Mean & SD & N & Mean & SD & N & Mean & SD \\
Pre-test & 26 & 7.50 & 6.52 & 25 & 7.60 & 5.61 & 51 & 7.55 & 6.03 \\
Post-test & 26 & 45.19 & 19.10 & 25 & 34.00 & 18.54 & 51 & 39.71 & 19.48 \\
Retention test & 26 & 51.54 & 21.34 & 25 & 37.20 & 18.32 & 51 & 44.51 & 21.01 \\
\hline
\end{tabular}

As presented in Table 3, pre-test, post-test and retention test mean scores of the experimental group students were found to be 7.50, 45.19 and 51.54 respectively. The mean scores of the control group students were 7.60, 34.00 and 37.20 for pre-test, post-test and retention test, respectively. The two-way analysis of variance (ANOVA) results for mixed measurements are presented in Table 4. 
Table 4

ANOVA Results of Pre-, Post-, and Retention Test FAT Scores

\begin{tabular}{lcccccc}
\hline Source of variance & $\begin{array}{c}\text { Squares } \\
\text { total }\end{array}$ & df & $\begin{array}{c}\text { Average of } \\
\text { squares }\end{array}$ & $F$ & $p$ & $\eta^{2}$ \\
\hline Between groups & & & & & & \\
$\quad$ Group (Experiment-control) & 2747.520 & 1 & 2747.520 & 4.962 & .031 & .092 \\
$\quad$ Error & 27132.872 & 49 & 553.732 & & & \\
Within groups & & & & & & \\
$\quad$ Measurement (pre/post/ret.) & 40875.976 & 2 & 20437.988 & 174.135 & .000 & .780 \\
$\quad$ Group*measurement & 1469.440 & 2 & 734.720 & 6.260 & .003 & .113 \\
$\quad$ Error & 11502.128 & 98 & 117.369 & & & \\
\hline
\end{tabular}

Table 4 shows that there was a statistically significant difference between the mean scores of the experimental and control groups $\left(F_{1-49}=4.962, \mathrm{p}<.05, \eta^{2}=.092\right)$. The experimental group students $(\bar{X}=45.19)$ were more successful than the control group students $(\bar{X}=34.00)$. However, being in different groups seems to have a moderate effect $\left(\eta^{2}=.092\right)$ on the achievement scores of the groups $(0.092<0.14)$. When pre-test, post-test, and retention test mean scores were compared, it was seen that repeated measures made a significant difference in students' achievement scores $\left(F_{1-49}=174.135, \mathrm{p}<.05, \eta^{2}=.780\right)$. It was seen that the process had a high-level effect $\left(\eta^{2}=0.780\right)$ on the change observed in students' achievement $(0.780>0.14)$. When the group and measurement joint effect was examined, it was seen that there was a statistically significant difference between the scores $\left(F_{1-49}=6.260, p<.05, \eta^{2}=.113\right)$.

According to these results, the change between pre-test, post-test, and retention test scores was significantly differentiated in terms of the teaching method applied in the experimental and control groups. It was seen that the common effect of group and measurement $\left(\eta^{2}=.113\right)$ was moderate $(0.113<0.14)$. Bonferroni test results are presented in Table 5.

Table 5

Multiple Comparisons of the Groups Pre-, Post-, and Retention Test FAT Scores

\begin{tabular}{|c|c|c|c|c|c|c|}
\hline \multirow[b]{2}{*}{$\begin{array}{l}\text { (I) } \\
\text { Measurement }\end{array}$} & \multirow{2}{*}{$\begin{array}{l}\text { (J) } \\
\text { Measurement }\end{array}$} & \multirow{2}{*}{$\begin{array}{c}\text { Mean } \\
\text { Difference } \\
\text { (I-J) }\end{array}$} & \multirow[b]{2}{*}{$S E$} & \multirow[b]{2}{*}{$p$} & \multicolumn{2}{|c|}{ 95\% Confidence Interval } \\
\hline & & & & & $\begin{array}{l}\text { Upper } \\
\text { Bound }\end{array}$ & $\begin{array}{l}\text { Lower } \\
\text { Bound }\end{array}$ \\
\hline \multirow{2}{*}{ Pre-Test } & Post-test & $-32.046^{*}$ & 2.088 & .000 & -37.221 & -26.871 \\
\hline & Retention test & $-36.819 *$ & 2.250 & .000 & -42.397 & -31.241 \\
\hline \multirow[t]{2}{*}{ Post-Test } & Pre-test & $32.046^{*}$ & 2.088 & .000 & 26.871 & 37.221 \\
\hline & Retention test & -4.773 & 2.096 & .081 & -9.968 & .422 \\
\hline Retention & Pre-test & $36.819^{*}$ & 2.250 & .000 & 31.241 & 42.397 \\
\hline Test & Post-test & 4.773 & 2.096 & .081 & -.422 & 9.968 \\
\hline
\end{tabular}

Table 5 shows that there was a statistically significant difference between the arithmetic averages of the groups' pre-test and post-test scores in favor of the experimental group $(p<.05)$. There was a statistically significant difference $(p<.05)$ in favor of the experimental group between the arithmetic averages of the groups' pre-test and retention test scores. There was no statistically significant difference between the arithmetic averages of the post-test and retention test scores of the groups $(p>.05)$.

\subsection{Pre-test and Post-test MAS Scores of Experimental and Control Group Students}

Before the analysis, it was determined that the assumptions of normality and homogeneity of variances were met, among the assumptions of two-way analysis of variance (ANOVA) for mixed measurements. No statistically significant difference was determined between the covariances $(p>0.5)$. The arithmetic mean and standard deviation values of the experimental and control group students' MAS, pre-test, and post-test scores are presented in Table 6. 
Table 6

Descriptive Data of Experimental and Control Group Students' Pre-and Post-test MAS Scores

\begin{tabular}{lccccccccc}
\hline & \multicolumn{3}{c}{ Experimental Group } & \multicolumn{3}{c}{ Control Group } & \multicolumn{3}{c}{ Total } \\
\hline & $\mathrm{N}$ & Mean & SD & N & Mean & SD & N & Mean & SD \\
Pre-test & 26 & 116.69 & 16.63 & 25 & 115.73 & 16.01 & 51 & 116.22 & 16.17 \\
Post-test & 26 & 125.96 & 11.71 & 25 & 109.43 & 14.58 & 51 & 117.85 & 15.50 \\
\hline
\end{tabular}

Table 6 shows that the pre-test and post-test mean scores of the experimental group students were found to be 116.69 and 125.96, respectively. The mean scores of the control group students were 115.73 and 109.43 for pre-test and post-test, respectively. The two-way analysis of variance (ANOVA) results for mixed measurements are presented in Table 7.

Table 7

ANOVA Results of Pre- and Post-test AMTS Scores

\begin{tabular}{lcccccc}
\hline Source of variance & $\begin{array}{c}\text { Squares } \\
\text { total }\end{array}$ & $d f$ & $\begin{array}{c}\text { Average of } \\
\text { squares }\end{array}$ & $F$ & $p$ & $\eta^{2}$ \\
\hline Between groups & 1947.633 & 1 & 1947.633 & 5.379 & .025 & .099 \\
$\quad$ Group (Experiment-control) & 17741.424 & 49 & 362.070 & & & \\
$\quad$ Error & & & & & & \\
Within groups & 55.980 & 1 & 55.980 & .712 & .403 & .014 \\
$\quad$ Measurement (pre/post/ret.) & 1545.884 & 1 & 1545.884 & 19.671 & .000 & .286 \\
$\quad$ Group*measurement & 3850.808 & 49 & 78.588 & & & \\
$\quad$ Error & & &
\end{tabular}

Table 7 shows that there was a statistically significant difference between the mean scores of the experimental and control groups $\left(F_{1-49}=5.389, p<.05, \eta^{2}=.099\right)$. However, being in different groups seemed to have a moderate effect $\left(\eta^{2}=.099\right)$ on the groups' MAS scores $(0.099<0.14)$. On the other hand, it was seen that repeated measurements did not make a significant difference in the MAS scores $\left(F_{1-49}=.712, p>.05\right)$. When the group and measurement joint effect was examined, it was seen that there was a statistically significant difference between the scores in favor of the experimental group $\left(F_{1-49}=19.671, \mathrm{p}<.05, \eta^{2}=.286\right)$. It was also seen that the group and measurement joint effect $\left(\eta^{2}=.286\right)$ was high $(0.286>0.14)$.

\subsection{Findings on Students' Views on Formative Assessment Practices}

With the first question in the interviews, the students were asked to compare the teaching of the functions topic with the previous math topics and to explain if there were any differences. The data on the themes that emerged from responses are presented in Table 8.

Table 8

Descriptive Data on Perceptions of Formative Assessment Practices

\begin{tabular}{|c|c|c|c|c|}
\hline Themes & Sub-themes & Representative responses & $f$ & $\%$ \\
\hline Strategies & $\begin{array}{l}\text { Learning Tasks } \\
\text { Feedback }\end{array}$ & $\begin{array}{l}\text { It was nice to have activities, quizzes, worksheets, } \\
\text { various videos, different things. (S3) } \\
\text { There were questions about daily life, activities, } \\
\text { journaling. (S11) }\end{array}$ & 20 & 55.56 \\
\hline Learning & $\begin{array}{l}\text { Clear and easy to } \\
\text { understand } \\
\text { Student } \\
\text { Participation } \\
\text { Permanent } \\
\text { Useful }\end{array}$ & $\begin{array}{l}\text { Yes, there are definitely differences. Especially the } \\
\text { activities we did were very helpful for me to learn. } \\
\text { (S10) } \\
\text { I expressed more easily what I was lacking and the } \\
\text { parts of the subject that I did not understand. (S4) }\end{array}$ & 11 & 30.56 \\
\hline Feelings & $\begin{array}{l}\text { Nice } \\
\text { Like } \\
\text { Comfortable }\end{array}$ & $\begin{array}{l}\text { I really liked the activities you did about daily life. (S5) } \\
\text { I felt more comfortable while working on functions. } \\
\text { Because we had the opportunity to talk more. (S1) }\end{array}$ & 5 & 13.89 \\
\hline
\end{tabular}


Table 8 shows that $55.56 \%$ of students referred formative assessment strategies, $30.56 \%$ of students mentioned the effect of formative assessment on learning and $13.89 \%$ of students indicated about feelings.

In another question, students were asked to explain whether the activities used in the lesson affected their learning processes. The data related to the themes that emerged as a result of the analysis of the answers are presented in Table 9.

Table 9

Students' Perceptions on the Activities Used in the Course

\begin{tabular}{|c|c|c|c|c|}
\hline Themes & Sub-themes & Representative responses & $f$ & $\%$ \\
\hline Strategies & $\begin{array}{l}\text { Learning Tasks } \\
\text { Success Criteria } \\
\text { Individual Learning } \\
\text { Feedback }\end{array}$ & $\begin{array}{l}\text { I think we progress more easily while doing } \\
\text { activities. Because what we will do about the } \\
\text { lesson that day was revealed more clearly with } \\
\text { the activities. I can say that the activities were } \\
\text { very useful in terms of revealing what we are } \\
\text { doing or what we will do. (S1) } \\
\text { Especially activities related to daily life were } \\
\text { conspicuous (S7) }\end{array}$ & 9 & 32.14 \\
\hline Learning & $\begin{array}{l}\text { Clear and easy to } \\
\text { understand } \\
\text { Student } \\
\text { Participation } \\
\text { Academic success } \\
\text { Interesting } \\
\text { Efficient } \\
\text { Useful }\end{array}$ & $\begin{array}{l}\text { There were yes, no, why questions at the } \\
\text { activities. Even if I made a mistake in the why } \\
\text { part, it was different to think about the reason } \\
\text { and to express the reasons for the actions. Before } \\
\text { this topic, we were just solving questions, not } \\
\text { talking about the reasons for our actions. (S1) } \\
\text { Activities are more interesting than usual lessons. } \\
\text { (S3) }\end{array}$ & 17 & 60.71 \\
\hline Feelings & Funny & It was a lot of fun while doing the activities. (S5) & 2 & 7.14 \\
\hline
\end{tabular}

Table 9 shows that $32.14 \%$ of students mentioned formative assessment strategies, $60.71 \%$ of students mentioned the effect of formative assessment on learning and $7.14 \%$ of students indicated about feelings.

The other question in the interviews was to determine whether the reflective prompts contributed students' learning process. Data on themes representing student responses to the related question are presented in Table 10.

Table 10

Students' Views on Reflective Prompts

\begin{tabular}{|c|c|c|c|c|}
\hline Themes & Sub-themes & Representative responses & $f$ & $\%$ \\
\hline Positive & $\begin{array}{l}\text { Individual } \\
\text { learning } \\
\text { Nice } \\
\text { Permanent } \\
\text { Useful }\end{array}$ & $\begin{array}{l}\text { I think it has a positive contribution to my learning } \\
\text { process. I kept the logs regularly. It allowed me to } \\
\text { see the parts I was lacking in learning. (S2) } \\
\text { I realize what I have done, what I have learned, } \\
\text { what I have understood and what I have not } \\
\text { understood. (S11) }\end{array}$ & 19 & 90.48 \\
\hline Negative & $\begin{array}{l}\text { Difficult } \\
\text { Useless }\end{array}$ & $\begin{array}{l}\text { I had a hard time writing the logs. It was difficult } \\
\text { for me to put my thoughts into words. I've never } \\
\text { kept a diary before. (S14) } \\
\text { I think it's unnecessary. (S12) }\end{array}$ & 2 & 9.52 \\
\hline
\end{tabular}

According to Table 10, $90.48 \%$ of the students pointed out positive comments on reflective prompts while $9.52 \%$ of them stated negative sides of them. 
In the last question of the interviews, students were asked to indicate whether they would like to continue with formative assessment practices in their mathematics lessons. Themes and subthemes generated from their responses are as summarized in Table 11.

Table 11

Student Perceptions on the Continuation of Formative Assessment Practices

\begin{tabular}{|c|c|c|c|c|}
\hline Themes & Sub-themes & Representative responses & $f$ & $\%$ \\
\hline Positive & $\begin{array}{l}\text { Beneficial } \\
\text { Enjoyable } \\
\text { Pleasant }\end{array}$ & $\begin{array}{l}\text { I think that formative assessment practices contribute } \\
\text { positively to my learning process. I want it to continue. } \\
\text { (S2) }\end{array}$ & 11 & 73.33 \\
\hline & Good & Yes, I would. Because I think it is useful. (S13) & & \\
\hline Negative & $\begin{array}{l}\text { Learning } \\
\text { environment }\end{array}$ & $\begin{array}{l}\text { It may be useful for friends who have difficulties in } \\
\text { learning the subjects, but I think it may be more useful } \\
\text { to solve more questions for university preparation rather } \\
\text { than spending time on activities. (S9) } \\
\text { Activities are of course very good, but I also think that it } \\
\text { is a waste of time. We can use the time spent on } \\
\text { activities for new topics. (S6) }\end{array}$ & 4 & 26.67 \\
\hline
\end{tabular}

As shown in Table 11, majority of the students (73.33\%) highlighted positive comments about continuation of formative assessment practices while about quarter of them $(26.67 \%)$ stated negative opinions.

\section{Discussion and Conclusion}

The purpose of this research was to examine the effects of formative assessment practices on students' achievement, attitudes towards mathematics, and to determine their views on formative assessment practices. The results revealed that formative assessment practices were statistically significant in improving students' mathematics achievement. Furthermore, formative assessment practices were found to be effective on students' attitudes towards mathematics. According to the qualitative findings of the study, the majority of the students had positive views on formative assessment practices.

The implementation of formative assessment practices in mathematics lessons for $10^{\text {th }}$ grade students has yielded significant results in terms of achievement. The findings obtained from the research coincided with the results of numerous studies in the literature (Andersson \& Palm, 2017; Box, 2019; Cormier, 2020; Faber et al., 2017; Kline, 2013; Ozan \& Kincal, 2018). Studies have shown that formative assessment practices have positive effects on learning at various grade levels (Loughland \& Kilpatrick, 2015; Thoms, 2011; Wanner \& Palmer, 2018). Its contribution to learning at all levels, from primary school to university, highlights the importance of formative assessment in terms of learning.

Various studies in the literature examined the effects of formative assessment practices on student achievement. Cormier (2020) concluded that formative assessment has higher achievement effects for low-performing students. On the other hand, Faber et al. (2017) concluded that formative assessment has higher achievement effects for high-performing students. Van den Berg et al. (2018) concluded that the formative assessment model in the classroom did not make a significant difference in student performance in another study. Rones (2019) concluded that feedback had a positive effect on students' thinking, goal orientation, and perceived autonomy. Finally, Golden (2019) concluded that students' formative assessment scores were a predictor of their summative assessment scores. Although current paper did not consider achievement-levels, revealed results that support the literature that it increases academic achievement, mathematics achievement in particular.

Other results obtained from this research revealed that formative assessment positively affected students' attitudes towards mathematics. Previous studies on the effect of formative assessment 
practices on students' attitudes supported the result of the research (Casey, 2005; Heo \& Sihn, 2017; Hwang \& Chang, 2011; Köksalan, 2019). Casey (2005) determined that formative assessment practices in science lessons positively affected the attitudes of $9^{\text {th }}$ grade students towards science lessons. Similarly Heo and Sihn (2017) determined that formative assessment practices had a positive effect on the attitudes of 4 th-grade students towards mathematics lessons. Hwang and Chang (2011) determined that formative assessment practices had a positive effect on 5th-grade students' attitudes towards local culture lessons. Contrary to these studies, Chauncey (2009) found that formative assessment practices did not have any effect on middle school students' attitudes towards science.

Students stated that the course contents clarified the learning evidence and success criteria and contributed positively to learning and that formative assessment practices facilitated the understanding and follow-up of the subjects. They also indicated that they felt comfortable during the implementation process. Furthermore, formative assessment practices were found to be beneficial in terms of recognizing the wrong and missing parts of the learning process and enhancing learning. Because students were an active part of the learning process in the classroom, formative assessment practices helped them take responsibility for their own learning experience. Group activities were referred to be beneficial in terms of seeing different perspectives and learning from each other. Studies found that self and peer-assessment improves students' learning and basic abilities such as taking more responsibility for their own learning (Wanner \& Palmer, 2018). Students' views on formative assessment practices are similar to those in the studies on formative assessment in the literature (Haroldson, 2012; Johnson, 2016; Köksalan, 2019; Ozan \& Kincal, 2018; Richards-Babb et al., 2015).

The qualitative findings of the research coincided with the quantitative findings. These findings revealed the positive effects of formative assessment practices in mathematics lessons on students' achievement of functions topic and attitudes towards mathematics. The results of the studies on formative assessment in the literature supported the results of the current study (Andersson \& Palm, 2017; Box, 2019; Cormier, 2020; Faber et al., 2017; Kline, 2013; Köksalan, 2019; Ozan \& Kıncal, 2018).

\section{Suggestions}

Although this paper provides important new data regarding the usefulness of formative assessment, there are some limitations to be considered. First, this research is limited to $10^{\text {th }}$ grade students and mathematics course. Therefore, future studies could also be carried out at different grade levels and in different courses. Second, we used formal and informal formative assessment practices together. Therefore, it is recommended to investigate the effects of formal and informal formative assessment practices on students' mathematics achievement and attitudes towards mathematics separately. Third, this intervention is limited to a 12-week implementation process. The effects of formative assessment practices with different cycle lengths can be investigated.

Several suggestions are recommended for the practitioners. The use of formative assessment practices can be encouraged through teachers' professional development programs. Content related to formative assessment practices can be included in the secondary school mathematics curriculum. It is recommended that teachers use formative assessment to support student-centered classrooms in teaching mathematics and to effectively evaluate students' mathematical competence in the learning process.

Acknowledgements. Approval was obtained from Çukurova University to conduct the study (52921519-044/-50091 no, 01.04.2019 date). In addition, approval for the conduct of the study was obtained from the National Education Directorate of the province where the study was conducted (Kahramanmaraş Provincial Directorate of National Education, 35776031-605.01-E.5355094 no, 13.03.2019 date). 


\section{References}

Altiparmak, K., Aklar, M. A., \& Dursun, G. (2017). If I were a math teacher for one day, what would I do/wouldn't do: Student opinions. Yüzüncü Yal University Journal of the Faculty of Education, 14(1), 11171140 .

Andersson, C., \& Palm, T. (2017). The impact of formative assessment on student achievement: A study of the effects of changes to classroom practice after a comprehensive professional development programme. Learning and Instruction, 49, 92-102. https:// doi.org/10.1016/j.learninstruc.2016.12.006

Ardington, A., \& Drury, H. (2017). Design studio discourse in architecture in Australia: The role of formative feedback in assessment. Art, Design \& Communication in Higher Education, 16(2), 157-170. https://doi.org/10.1386/adch.16.2.157_1

Baird, J. A., Andrich, D., Hopfenbeck, T. N., \& Stobart, G. (2017). Assessment and learning: fields apart? Assessment in Education: Principles, Policy \& Practice, 24(3), 317-350. https:// doi.org/10.1080/0969594x.2017.1319337

Barber, B. K., \& Schluterman, J. M. (2008). Connectedness in the lives of children and adolescents: A call for greater conceptual clarity. Journal of Adolescent Health, 43(3), 209-216. https://doi.org/10.1016/j.jadohealth.2008.01.012

Beesley, A. D., Clark, T. F., Dempsey, K., \& Tweed, A. (2018). Enhancing formative assessment practice and encouraging middle school mathematics engagement and persistence. School Science and Mathematics, 118(1-2), 4-16. https://doi.org/10.1111/ssm.12255

Bower, J., van Kraayenoord, C., \& Carroll, A. (2015). Building social connectedness in schools: Australian teachers' perspectives. International Journal of Educational Research, 70, 101-109. https://doi.org/10.1016/j.ijer.2015.02.004

Box, C., (2019). Formative assessment in United States classrooms changing the landscape of teaching and learning. Palgrave Macmillan. https://doi.org/10.1007/978-3-030-03092-6

Büyüköztürk, Ş., Çakmak, E. K., Akgün, Ö. E., Karadeniz, Ş., \& Demirel, F. (2019). Bilimsel araştırma yöntemleri [Scientific research methods] (26th ed.). Pegem.

Casey, S. (2005). Formative assessment: the effect on academic achievement and attitudes toward science. Theses and Dissertations, 974. Rowan University. http://rdw.rowan.edu/etd/974

Cauley, K. M., \& McMillan, J. H. (2010). Formative assessment techniques to support student motivation and achievement. The Clearing House: A Journal of Educational Strategies, Issues and Ideas, 83(1), 1-6. https://doi.org/10.1080/00098650903267784

Chauncey, P. D. (2009). Perceptions and attitudes of formative assessments in middle-school science classes (Order No. 3379801). ProQuest Dissertations \& Theses Global. (305078889).

Chen, I. H., Gamble, J. H., Lee, Z. H., \& Fu, Q. L. (2020). Formative assessment with interactive whiteboards: A one-year longitudinal study of primary students' mathematical performance. Computers $\mathcal{E}$ Education, 150, 103833. https:// doi.org/10.1016/j.compedu.2020.103833

Cohen, J. (1988). Statistical power analysis for the behavioral sciences (2nd ed.). Lawrence Erlbaum.

Cormier, K. (2020). The use of ongoing formative standards-based assessments to improve student learning in an eighth grade mathematics classroom (Order No. 27956608). ProQuest Dissertations \& Theses Global. (2412152148).

Cowie, B., \& Moreland, J. (2015). Leveraging disciplinary practices to support students' active participation in formative assessment. Assessment in Education: Principles, Policy \& Practice, 22(2), 247-264. https://doi.org/10.1080/0969594x.2015.1015960

Cramp, A. (2011). Developing first-year engagement with written feedback. Active Learning in Higher Education, 12(2), 113-124. https://doi.org/10.1177/1469787411402484

Crossouard, B. (2011). Using formative assessment to support complex learning in conditions of social adversity. Assessment in Education: Principles, Policy $\mathcal{E}$ Practice, 18(1), 59-72. https://doi.org/10.1080/0969594X.2011.536034

Eddy, C. M., Harrell, P., \& Heitz, L. (2017). An observation protocol of short-cycle formative assessment in the mathematics classroom. Investigations in Mathematics Learning, 9(3), 130-147. https://doi.org/10.1080/19477503.2017.1308699

Edmonds, W. A., \& Kennedy, T. D. (2017). An applied guide to research designs: Quantitative, qualitative, and mixed methods (4th ed.). Sage Publications. 
Er, G., \& Biber, A. Ç. (2020). Thematic and methodological trends in experimental pattern theses in the field of mathematics education. Trakya Journal of Education, 10(3), 995-1006. https://doi.org/10.24315/tred.708202

Faber, J. M., Luyten, H., \& Visscher, A. J. (2017). The effects of a digital formative assessment tool on mathematics achievement and student motivation: Results of a randomized experiment. Computers $\mathcal{E}$ Education, 106, 83-96. https://doi.org/10.1016/j.compedu.2016.12.001

Fisher, D., \& Frey, N. (2014). Checking for understanding: Formative assessment techniques for your classroom. ASCD.

Frey, N., Fisher, D., \& Hattie, J. (2018). Developing "assessment capable" learners. Educational Leadership, 75(5), 46-51.

Golden, J. B. (2019). The relationship between formative math assessments and the state summative assessment for middle school students in Alabama (Order No. 27544015). ProQuest Dissertations \& Theses Global (2316839127).

Gotwals, A. W., Philhower, J., Cisterna, D., \& Bennett, S. (2015). Using video to examine formative assessment practices as measures of expertise for mathematics and science teachers. International Journal of Science and Mathematics Education, 13(2), 405-423. https:// doi.org/10.1007/s10763-015-9623-8

Haroldson, R. A. (2012). Student perceptions of formative assessment in the chemistry classroom (Order No. 3519170). ProQuest Dissertations \& Theses Global. (1034595383).

Hattie, J., \& Clarke, S. (2018). Visible Learning: Feedback. Routledge, https://doi.org/10.4324/9780429485480

Heo, G., \& Sihn, H. (2017). The effect of formative evaluation through mutual feedback on mathematics academic achievement and mathematics attitude. Journal of the Korean Mathematical Education Association Series E: Journal of Mathematical Education, 31(4), 409-432. https://doi.org/10.7468/JKSMEE.2017.31.4.409

Hwang, G. J., \& Chang, H. F. (2011). A formative assessment-based mobile learning approach to improving the learning attitudes and achievements of students. Computers $\mathcal{E}$ Education, 56(4), 1023-1031. https://doi.org/10.1016/j.compedu.2010.12.002

Johnson, A. (2016). The implementation and evaluation of formative feedback on students' attitudes and perceptions on their learning: An action research (Order No. 10006523). ProQuest Dissertations \& Theses Global. (1762590105).

Keeley, P. (2015). Science formative assessment: Practical strategies for linking assessment, instruction, and learning. Corwin Press.

Kline, A. J. (2013). Effects of formative assessment on middle school student achievement in mathematics and reading (Order No. 1538121). ProQuest Dissertations \& Theses Global (1370241304).

Köksalan, S. (2019). Examination of effects of formative assessment in inquiry-based learning on students' conceptual learning and attitudes towards physics [Unpublished Master's thesis]. Marmara University, İstanbul.

Loughland, T., \& Kilpatrick, L. (2015). Formative assessment in primary science. Education 3-13, 43(2), 128141. https:// doi.org/10.1080/03004279.2013.767850

Martin, I. (2010). Handbook of formative assessment - Edited by Heidi L Andrade \& Gregory J Cizek. British Journal of Educational Technology, 41(3), E59. https://doi.org/10.1111/j.1467-8535.2010.01080_2.x

Miles, M.B. \& Huberman, A.M. (1994). Qualitative data analysis: An expanded sourcebook (2nd ed.). Sage.

Ministry of National Education, [MoNE] (2018). Secondary school mathematics (9th, 10th, 11th and 12th grades) curriculum. Author.

Moreno, J., \& Pineda, A. F. (2020). A framework for automated formative assessment in mathematics courses. IEEE Access, 8, 30152-30159. https:// doi.org/10.1109/access.2020.2973026

Moss, C. M., \& Brookhart, S. M. (2019). Advancing formative assessment in every classroom: A guide for instructional leaders. ASCD.

Ozan, C., \& Kincal, R. Y. (2018). The effects of formative assessment on academic achievement, attitudes toward the lesson, and self-regulation skills. Educational Sciences: Theory \& Practice, 18, 85-118. http://dx.doi.org/10.12738/estp.2018.1.0216

Özgen, K., \& Alkan, H. (2014). The effects of learning activities according to students' learning styles on students' academic success and attitude: The sampling of function and derivative conception.Turkish Journal of Computer and Mathematics Education (TURCOMAT), 5(1), 1-38.

Panadero, E., \& Alonso-Tapia, J. (2013). Self-assessment: Theoretical and practical connotations. When it happens, how is it acquired and what to do to develop it in our students. Electronic Journal of Research in Educational Psychology, 11, 551-576. 
Panadero, E., Jonsson, A., \& Botella, J. (2017). Effects of self-assessment on self-regulated learning and selfefficacy: Four meta-analyses. Educational Research Review, 22, 74-98. https://doi.org/10.1016/j.edurev.2017.08.004

Richards-Babb, M., Curtis, R., Georgieva, Z., \& Penn, J. H. (2015). Student perceptions of online homework use for formative assessment of learning in organic chemistry. Journal of Chemical Education, 92(11), 18131819. https://doi.org/10.1021/acs.jchemed.5b00294

Rones, D. D. (2019). Student and teacher response to formative assessment feedback in eighth-grade mathematics: A design experiment (Order No. 13856648). ProQuest Dissertations \& Theses Global. (2248614511).

Sadler, D. R. (1989). Formative assessment and the design of instructional systems. Instructional Science, 18(2), 119-144.

Schoenfeld, A. H. (2016). Research in mathematics education. Review of Research in Education, 40(1), 497-528. https://doi.org/10.3102/0091732X16658650

Schunk, D. H. (2012). Learning theories an educational perspective (6th ed.). Pearson. https://doi.org/10.1017/ CBO9781107415324.004

Selçuk, Z., Palancı, M., Kandemir, M., \& Dündar, H. (2014). Trends of research published in the journal of education and science: Content analysis. Education and Science, 39(173). 430-453.

Swan M., \& Foster C. (2018). Formative assessment lessons. In Thompson, D., Burton M., Cusi A., \& Wright D. (Eds.) Classroom assessment in mathematics (pp.11-24). Springer. https://doi.org/10.1007/978-3-319-73748-5_2

Tai, J., Ajjawi, R., Boud, D., Dawson, P., \& Panadero, E. (2018). Developing evaluative judgement: enabling students to make decisions about the quality of work. Higher Education, 76(3), 467-481. https://doi.org/10.1007/s10734-017-0220-3

Teuscher, D., \& Reys, R. (2010). Slope, rate of change, and steepness: Do students understand the concepts? Mathematics Teacher, 103(7), 519-524. https://doi.org/10.2307/20876682

Thoms, B. (2011). A dynamic social feedback system to support learning and social interaction in higher education. IEEE Transactions on Learning Technologies, 4(4), 340-352. https ://doi.org/10.1109/TLT.2011.9

Van den Berg, M., Bosker, R. J., \& Suhre, C. J. (2018). Testing the effectiveness of classroom formative assessment in Dutch primary mathematics education. School Effectiveness and School Improvement, 29(3), 339-361. https:// doi.org/10.1080/09243453.2017.1406376

Wanner, T., \& Palmer, E. (2018). Formative self-and peer assessment for improved student learning: the crucial factors of design, teacher participation and feedback. Assessment $\mathcal{E}$ Evaluation in Higher Education, 43(7), 1032-1047. https:// doi.org/10.1080/02602938.2018.1427698

Wiliam, D., \& Thompson, M. (2007). Integrating assessment with instruction: What will it take to make it work? In C. A. Dwyer (Ed.), The future of assessment: Shaping teaching and learning (pp. 53-82). Lawrence Erlbaum Associates.

Wisniewski, B., Zierer, K., \& Hattie, J. (2020). The power of feedback revisited: a meta-analysis of educational feedback research. Frontiers in Psychology, 10, 3087.https:// doi.org/10.3389/fpsyg.2019.03087

Wylie, E. C. (2020). Observing Formative Assessment Practice: Learning Lessons Through Validation. Educational Assessment, 25(4), 251-258. https://doi.org/10.1080/10627197.2020.1766955

Xiao, Y., \& Yang, M. (2019). Formative assessment and self-regulated learning: How formative assessment supports students' self-regulation in English language learning. System, 81, 39-49. https://doi.org/10.1016/j.system.2019.01.004

Yalçınkaya, Y., \& Özkan, H. H. (2012). Content analysis of articles related to alternative methods of teaching mathematics published in education faculties journals between 2000-2011. Journal of Süleyman Demirel University Social Sciences Institute, 2(16), 31-45.

Yaşar, M., Çermik, H., \& Güner, N. (2014). High school students' attitudes towards mathematics and factors affect their attitudes in Turkey. Ankara University Journal of Faculty of Educational Sciences, 47(2), 41-64.

Zheng, L., Cui, P., Li, X., \& Huang, R. (2018). Synchronous discussion between assessors and assessees in web-based peer assessment: Impact on writing performance, feedback quality, meta-cognitive awareness and self-efficacy. Assessment $\mathcal{E}$ Evaluation in Higher Education, 43(3), 500-514. https://10.1080/02602938.2017.1370533 


\section{Appendix 1.}

1. When you compare the teaching of the functions topic with the previous math topics, are there any differences? Can you explain?

2. How did the activities used in the lesson affect your learning process? Can you explain?

3. Have your reflective prompts contributed to your learning process? Can you explain?

4. Would you like to continue formative assessment practices in mathematics lessons?" 